direct approach of drilling down into the Earth. As Dr. Gaskell pointed out, it is only the cost of drilling to the Mohorovičić discontinuity that is holding the project back: it would be possible from a technical point of view to start to-day. This is especially true of the proposal to drill through the sediments that cover the floor of the deep oceans.

Prof. Pettersson is, of course, ono of the world's experts in the deep-sea sediments, but even with his best corers he has managed to penetrate only the top $20 \mathrm{~m}$. of the sea-bed. He points out how important the complete column of deep-ocean sediments will be, because they must surely contain the history of the past geological behaviour of the Earth. Prof. Pettersson does not mention the United States Navy research project which has been set up to look into the economics and desirability of the Mohorovičić and deep-ocean sediments projects which were suggested at the Toronto International Geophysical Meeting in 1957, nor does he say anything about the rumoured Russian attempts to be first in this field.

\section{Regional Museum Council}

For many years the Museums Association has endeavoured to obtain some form of assistance from the Government for the smaller museums in Britain. It is well known that in several instances the position is desperate, and valuable material is being lost for want of proper conservation. During the past eighteen months a committee of inquiry in the southwest of England has accumulated facts, and at a meeting at Taunton on January 8 presented a report on the present position of museums in its area together with a series of maps indicating the distribution and size of the collections in the fields of archæology, applied art, fine art, botany, folk-lore, furniture, geology, numismatics and zoology. Dr. W. E. Swinton, president of the Museums Association, was in the chair for this, what may well prove to be a historic, occasion.

After full consideration of the report, it was decided to form a Regional Museum Council. The scope of this Council will include the counties of Bristol, Cornwall, Devon, Dorset, Gloucestershire, Somerset and Wiltshire and the town of Newport in Monmouthshire, while its objects will be to promote co-operation, improve technical facilities and to grant financial assistance to museums and art galleries within the region. The Council will consist of twenty-two members, and it has power to co-opt and make provision for alternate members. Sir John Hobhouse has been appointed chairman and Mr. F. J. Stott vice-chairman of the Council. The outcome of this initial effort on the part of the museums of the south-west of England will be awaited with interest, for if successful it will probably be followed by other regional councils in various parts of the British Isles.

\section{United States Atomic Energy Commission Training \\ Courses}

The U.S. Atomic Energy Commission has made grants totalling 2,264,965 dollars to forty-one universities and colleges in the United States for the purchase of laboratory equipment needed to expand their nuclear educational programmes. These grants include funds to seven engineering institutions, namely, Kansas State College and the Universities of Illinois, Maryland, Texas, Washington, West Virginia and Wisconsin, for the purchase of teaching reactors. The seven reactor grants bring to thirty the total number of teaching reactors in operation or to be constructed in American universities with the help of Commission grants.

The U.S. Atomic Energy Commission has also started a new programme of assistance to colleges and universities in the United States for education and training in radioisotope principles and technology. Direct financial assistance is to be given in obtaining demonstration apparatus, student laboratory equipment and training aids needed to offer adequate laboratory course-work in radioisotope technology.

\section{Pyrite Granules and Fossil Micro-organisms}

SMaLl spheres, usually less than $50 \mu$ across, composed of tightly packed pyrite crystals, are common in sedimentary rocks. They have been noted in rocks of both marine and freshwater origin, from those of the Cambrian to present-day sediments, and have previously usually been considered to be of inorganic origin or to have been associated with the activities of sulphur bacteria. L. G. Lowe has recently shown that spheres of this kind from certain beds of the Scottish Lower Carboniferous oil shale group enclose microfossils of a hitherto unknown group (Quart. $J$. Geol. Soc., 113, 429; 1958). The two new monotypic genera, Pyritosphaera and Pyritella, are both rounded in form and apparently multicellular, the surface of the former being covered with radial spines. The affinities of these genera cannot at present be defined, but they are evidently not bacteria. It is suggested that during their life-time the organisms generated hydrogen sulphide as a by-product of the anaerobic decomposition of sulphur compounds (probably sulphates) and that the gas reacted with iron ions to precipitate iron sulphide on their surfaces. It remains to be seen whether future studies will reveal a range of genera and species capable of being used as stratigraphic or environmental indices, as has been the case with so many other types of microfossils in recent years, but it seems clear that where found Pyritosphaera and Pyritella demonstrate stagnant conditions at the time the containing sediment was formed.

\section{Morhana Parar}

THE issue of Man of last October contains an interesting article by Dr. Allchin which deals with a number of deep rock shelters in India, called Morhana Parar, which have yielded numerous pigmy tools, and the walls and ceilings of which have been painted. The sites, near the village of Bhainswar, some 42 miles south of Mirzapur on the Great Deccan Road, had been investigated as long ago as 1880 by A. C. Carlleyle, who died before he had been able to deal with his discoveries, and the caves had been forgotten. Some of the 'loot', however, seems to have found its way into several European museums and collections. Now the sites have been rediscovered and studied by Dr. Allchin. The paintings consist of hunting and dancing scenes, chariots and animals. It is to be presumed that the makers of the pigmy tools were the painters.

\section{Disposal of Radioactive Waste}

A DETAILED study of the microbiology and water circulation in the Black Sea by A. E. Kriss (Priroda, $6,43 ; 1958)$ and the water circulation in oceans by V. G. Bogorov and E. M. Kreps (Priroda, 9, 45; 1958) show that the vertical circulation of sea and 